\title{
Blandowski misses out: ichthyological etiquette in 19th-century Australia
}

\author{
Paul Humphries \\ Cooperative Research Centre for Freshwater Ecology, Department of Biological Sciences, Monash University, \\ c/- Murray-Darling Freshwater Research Centre, PO Box 921, Albury, NSW 2640, Australia
}

\begin{abstract}
Wilhelm Blandowski, a Prussian émigré, arrived in Australia in 1849 with hopes of exploring and documenting the natural history of this still relatively scientifically naïve colony. After several years travelling, surveying and mining gold, he became the first government zoologist at the infant National Museum of Victoria and was a key player in the burgeoning scientific establishment. Chosen to lead a collecting expedition to the junction of the Murray and Darling Rivers in 1856, Blandowski and his faithful companion Gerard Krefft brought back a wealth of new material, including many species of undescribed freshwater fishes. Unfortunately, Blandowski's attempts to 'honour' members of the Philosophical Institute of Victoria backfired and a scandal ensued. A disillusioned Blandowski left Australia just ten years after his arrival. A reanalysis of his descriptions of the fish and comparison with a contemporary work suggests that Blandowski deserves recognition as one of pioneers in the natural history of Australian freshwater fish. The loss of taxonomic authority for eight fish species by this energetic, imaginative, but stubborn scientist, left the way open for future workers to make their mark, whereas Blandowski's name and achievements remain obscure.
\end{abstract}

On the 3 September 1857 at Wedel's Criterion Hotel in Melbourne, Australia, a special dinner was held by forty members of the Philosophical Institute of Victoria in honour of Wilhelm Blandowski (1822-1880?) (Fig. 1), government zoologist and recently returned leader of an expedition to the junction of the Murray and Darling Rivers in southern Australia [1]. Speeches and toasts were made, and praises sung of this man who had been, until then, the greatest promoter of natural history in the colony of Victoria, and who also had been instrumental in helping form the fledgling National Museum in Melbourne. Mr Blandowski thanked those present and modestly stated that '...the honour which had been done to him had far exceeded the services he had performed' [2]. Unfortunately, the honour to which Blandowski referred did not last long, and the course of events which followed resulted in his leaving Australia after ten years of studying natural history, and his relegation to virtual obscurity in the annals of Australian science.

Corresponding author: Paul Humphries (paul.humphries@csiro.au).
The rot set in when, shortly after the dinner, Blandowski presented a preliminary paper to the Philosophical Institute on the findings of his expedition. As was often the custom in those days, Blandowski decided to honour members of the Institute by naming apparently new species of fish after them. This had, in fact, been just what Ferdinand Mueller had done the previous month for various plant species and everything had gone smoothly [3]. Blandowski presented, amongst descriptions of plants, birds, reptiles, mammals and aborigines, what he proposed as 'nineteen new forms of fishes' that he had collected (Fig. 2). Only three species, he claimed, had been described before - a remarkable scientific achievement. The drawings of the fish were exquisite and

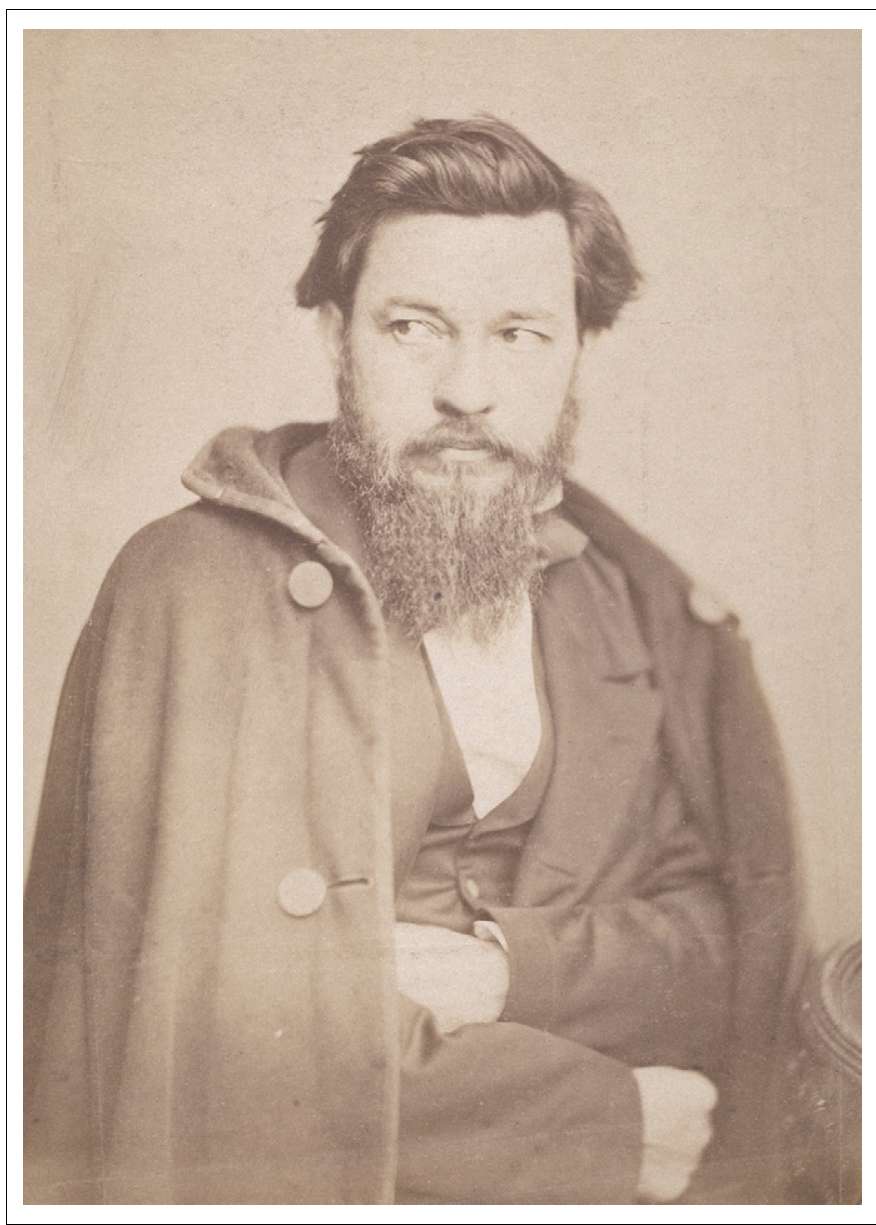

Fig. 1. William Blandowski Polish/German (1822-1876), active in Australia 1849-1859. Self portrait, albumen silver photograph, $22.3 \times 17.4 \mathrm{~cm}$ irreg. (image and sheet). Purchased, 1994. National Gallery of Victoria, Melbourne. 


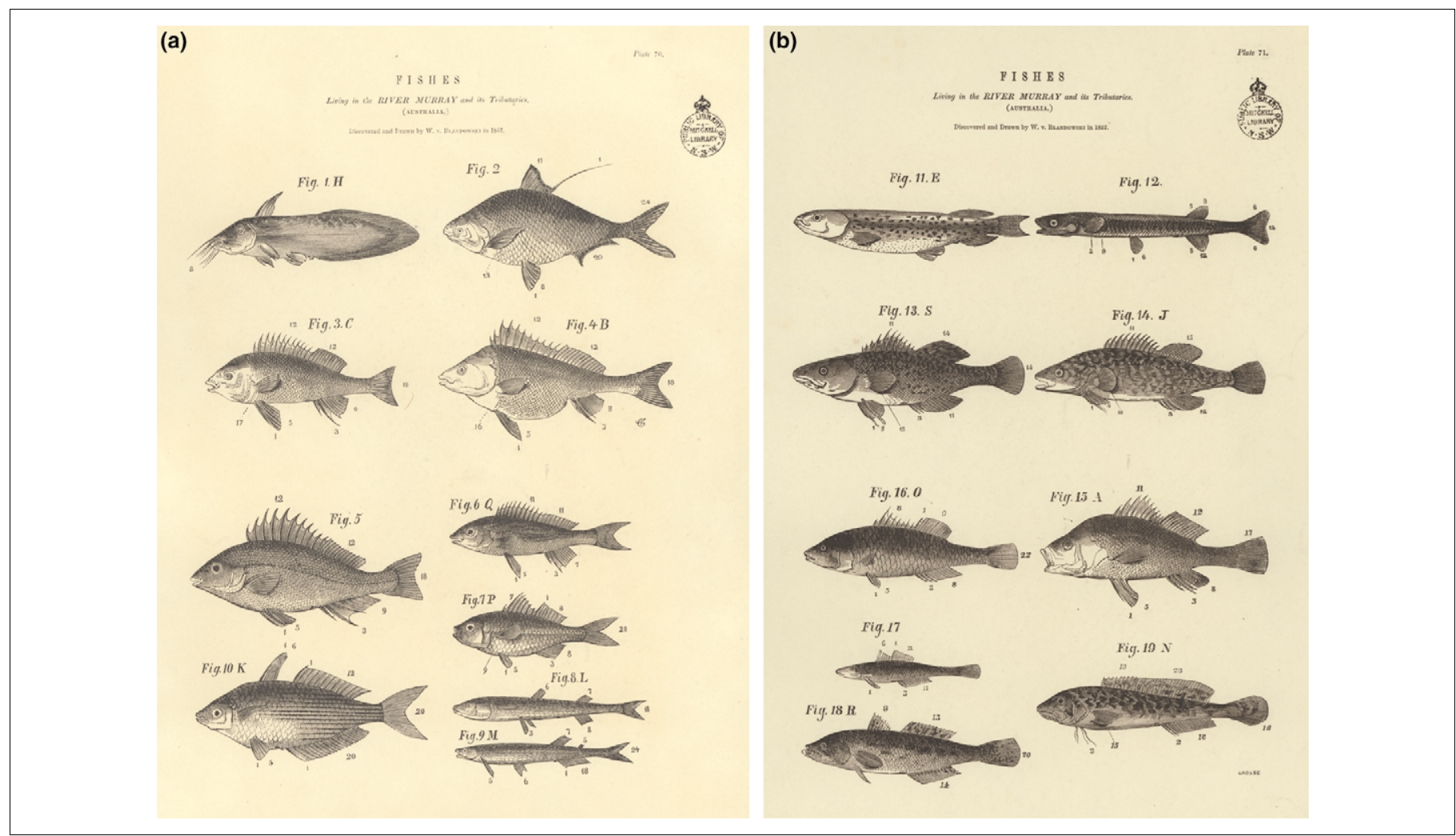

Fig. 2. Fishes living in the River Murray and its tributaries, discovered and drawn by W. v. Blandowski in 1857. 'Fig. 4B' depicts the silver perch, Cernua eadesii, named after Dr Richard Eades (Fig. 3a). 'Fig. 19 ' depicts the river blackfish, Brosmius bleasdalii, named after the Revd Dr John Ignatius Bleasdale (Fig. 3b). Reproduced from the State Library of NSW, PXE 864.

would no doubt have drawn much praise from those assembled to hear his paper, but the descriptions of two of the species and their corresponding nomenclature were not received well by two of the men present.

The silver perch, Cernua eadesii [4] - called 'buruitjall' by the local Yaree Yaree aboriginal tribe - was named after Dr Richard Eades (1809-1867), a physician at Melbourne Hospital and one of the cofounders of the Philosophical Institute (Fig. 3a). It was described as nothing more and, indeed, nothing less than 'A fish easily recognized by its low forehead, big belly and sharp spine'. Another species, the river blackfish, Brosmius bleasdalii [5] - called 'paltk' by the Yaree Yaree - was named after the Revd Dr John Ignatius Bleadsdale (1822-1884) (Fig. 3b), later to become president of the Royal Society of Victoria. 'A slippery fish. Lives in the mud.' was Blandowski's description [6] The Philosophical Institute was up in arms.

Some saw the names and descriptions as merely harmless, whilst others saw a deliberate attempt to besmirch reputations and lampoon well-respected members of the Institute. There had been some disagreements between Blandowski and the Institute and the matter of monies owed for wages and also the ordering of the recall of the expedition party, which had, as of September 1857, still been collecting in the absence of the party's leader. So, there is an element of doubt over Blandowski's motives. There had also been simmering tensions between Blandowski and Frederick McCoy, who had become director of the museum before the expedition's departure. Debate ensued and an inquiry was held, and arguments for both sides were published in the local newspaper, The Argus:
The precise words in which these alleged satires are couched we do not know, but we understand that a local habitation and a name having to be given to certainly newly-discovered fish, it was proposed to immortalize some members of the Institute by calling the said fish after them. Among these gentlemen were Dr Eades and Rev Mr Bleasdale. The fish called after Dr Eades was described as having a receding forehead and a large belly. Dr Eades seems to think that in this description Mr Blandowski has some kind of arriere pensée to peculiarities in the conformation of the Doctor's frontal and abdominal regions, and the Rev. Mr Bleasdale thinks the same about the tittlebat Bleasdaliensis, or whatever the fish may be to which the reverend gentleman's name had been attached [7].

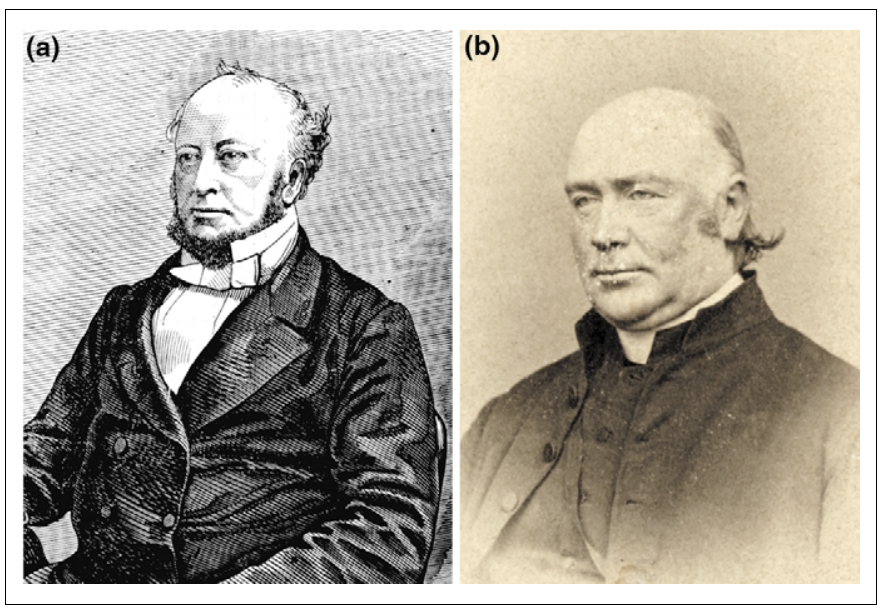

Fig. 3. Slighted members of the Philosophical Institute. (a) Dr Richard Eades (1809-1867). Reproduced from State Library of Victoria, Library Record Number: 906729, Accession Number: IMP16/08/62/1. (b) Revd Dr John Ignatius Bleasdale (1822-1884). Reproduced from State Library of Victoria, H3075. 
The Council of the Institute asked for a written explanation and the removal of the descriptions. Blandowski refused. Later, the council had the paper published with the offending pages about the fish taken out. A special Committee of Inquiry essentially exonerated Blandowski, stating that the offending descriptions of the particular fish were not unusual when compared with descriptions of the other species, but the matter did not rest there. At the meeting to discuss the findings of the Committee of Inquiry, accusations and counter accusations were in full flight, and tempers, already frayed, came apart at the seams. Blandowski asserted that Eades had in fact been shown the engravings of the fish and had chosen which one was to be named after him and had pencilled his name underneath it. Eades emphatically denied this. Bleasdale and another member threatened to resign, but the members present voted not to accept their resignations. A motion to oust Blandowski at the next meeting failed. Nevertheless, the blow to the ichthyologist was considerable, and dismayed by the whole process, he lost interest in the society and was to read only one more paper before it.
The scandal was grist to the mill for Melbourne periodicals at the time. They had been following with great interest, almost bordering on blood-lust, the formation and machinations of the various incarnations of scientific societies and the National Museum of Victoria in the colony. The Argus, in particular, had been noting Blandowski's enthusiasm, his contribution to natural history and his role in the new museum. The periodicals were also very aware of the politics within the societies and the sensitivities of various members. Bleasdale was a prominent figure in Melbourne society and was a frequent correspondent with the Argus and received his fair share of criticism from them, often overtly prejudiced because he was a catholic [8]. Melbourne Punch typically took a satirical approach and published a verse and cartoon lampooning the whole episode (Box 1) [9].

It turned out that Blandowski had never formally returned for work after the expedition and there was a nasty battle when the Surveyor General demanded that all the drawings and notes made during the year-long foray into the countryside at the Government's expense be

\section{Box 1. A satirical take on the Blandowski affair, published in Melbourne Punch [9] (Fig. I)}

\begin{tabular}{|c|c|}
\hline $\begin{array}{l}\text { AN EXPLANATION } \\
\text { By a Distinguished Foreigner, and Member of the Philosophical Institute }\end{array}$ & $\begin{array}{l}\text { Ze belly black vith spots of blue, } \\
\text { I wrote so, for ze ting vos true. }\end{array}$ \\
\hline $\begin{array}{l}\text { Vot shall I say, vot shall I do- } \\
\text { I did describe ze vish quite tue; }\end{array}$ & $\begin{array}{l}\text { Vot should I tink ze man had got, } \\
\text { A black stomach with purple spot. }\end{array}$ \\
\hline $\begin{array}{l}\text { I wish zat I could please you all, } \\
\text { But not can make his belly small? }\end{array}$ & $\begin{array}{l}\text { Vot color may be of his skin, } \\
\text { I think it must be very tin }\end{array}$ \\
\hline $\begin{array}{l}\text { Mein himmel - all vot I wish, } \\
\text { You look yourself upon ze vish; }\end{array}$ & $\begin{array}{l}\text { All over all dese gentlemens'. } \\
\text { Or dey would not so take offense. }\end{array}$ \\
\hline $\begin{array}{l}\text { You see ze spines - ze little pins, } \\
\text { Vot sticks out here upon his fins. }\end{array}$ & $\begin{array}{l}\text { Another vish, I did him call, } \\
\text { After a great man vish is small; }\end{array}$ \\
\hline $\begin{array}{l}\text { This oderr vish has got ze same, } \\
\text { But he has got anoder name }\end{array}$ & $\begin{array}{l}\text { And ze report of zis great gun, } \\
\text { Make out I turn him into fun. }\end{array}$ \\
\hline $\begin{array}{l}\text { Because he differs in his belly, } \\
\text { Vich is all vlat, not round and swelly. }\end{array}$ & $\begin{array}{l}\text { I tell you zat I had not thought } \\
\text { To say zat vot I didn't ought; }\end{array}$ \\
\hline $\begin{array}{l}\text { But zat von mit de stomach flat, } \\
\text { You see about ze head is vlat- }\end{array}$ & $\begin{array}{l}\text { It vos no part of mein own wishes, } \\
\text { To miscal men while naming vishes. }\end{array}$ \\
\hline
\end{tabular}

You see about ze head is vlat-

Shall I about him tell some lies,

Because ze doctor's is likewise?

Vot for, I ask, am I to blame

Because ze vish is zhaped ze same?

I cannot take his stomach in,

Nor make ze doctor small and tin.

Vell, here now is another vish;

$A$ reverend gentleman did vish

Zat I should give a vish his name,

And I did choose ze first vot came.

I did not think of them at all;

I see my vish, and zat is all.

But, gentlemans, you please to note

Zees little tings about his troat.

Vell, it is inze fish's blood,

Vot has got zese to love ze mud.

And I may tell you at dis time

Such vishes always has some slime.

Now, really very much I vish

You pay attention to my vish;

Upon his belly there is lots

Of little blue or purple spots.

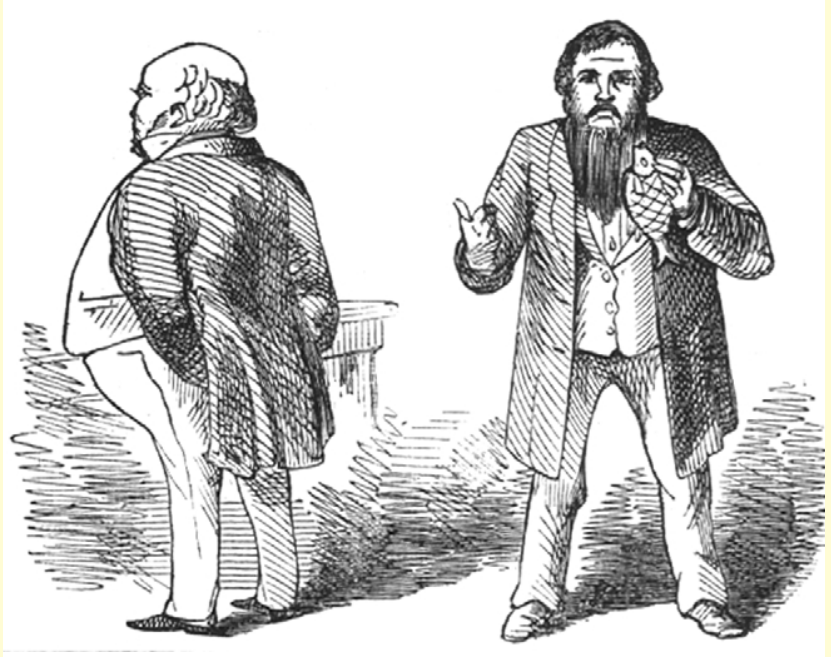

Fig. I. Blandowski holding a fish and presumably one of the members of the Philosophical Institute trying to ignore it. Reproduced from [9]. 
handed over. Blandowski argued that, as many of the descriptions and drawings were done in his spare time and on Sundays, these were his private property. Because of ongoing disagreements between Blandowski and various components of the Colonial Government, he finally left Australia on the 17 March 1859 on the Mathilde, sailed via the East Indies and then to Europe. There were rumours at the time and, indeed, this rumour persists, that Blandowski had kept many specimens for himself and took them with him when he left. However, this is unlikely, because all specimens were catalogued, each bears a unique number and the catalogue still exists and bears Blandowski's signature [10].

\section{Wilhelm Blandowski and the expedition to the lower Murray}

Wilhelm Blandowski (or William as he was known in Australia) was born on the 21 January 1822 in Gliwice, Upper Silesia, the son of a Prussian Lieutenant Colonel of the Medical Corp [11]. In 1849, he sailed from Hamburg to Adelaide, one of a distinguished group of eastern European natural historian/explorers who came to Australia in the first half of the 19th century hoping to make a name and to further the science of this largely unknown continent [12]. It seems likely that he was sponsored as a 'collector' by one or more wealthy German men, who commonly sent others overseas to seek specimens of animals, but more commonly plants, for their private or official museum collections [13]. He wanted to '...compile a natural history, a botanical classification and a geological arrangement of this country' [14], and whilst pursuing those ends in South Australia, around Sydney, Brisbane and Cape York during 1850 and 1851, did so largely without government support; not, however, through want of trying.

By 1852, Blandowski had moved to Victoria, was involved with the founding the Geological Society of Victoria, and had been lured, like so many thousands of others, to the goldfields. Here, he developed a water pump, which allowed the gold from flooded mines to be extracted more efficiently, and presumably made a considerable sum of money. He continued to lobby governments for financial support to research and publish his natural history work, but was largely unsuccessful. However, he was gradually making a name for himself, and in late 1853 was asked to comment on the formation of a Museum of Practical Geology. His professional assessment and personal determination clearly impressed Governor La Trobe and, when the Museum of Natural History was founded instead, Blandowski was appointed as 'Government Zoologist'.

Immediately, he began collecting specimens for the museum and presenting papers at the Philosophical Society of Victoria, of which he was an inaugural member. Indeed, between 1855 and 1856, he wrote on topography, geology, zoology (including fish, molluscs, birds, frogs, reptiles and mammals) and anthropology [15]. But his big break came when the government managed to find 2000 pounds to fund an expedition to the junction of the Murray and Darling Rivers near the borders of Victoria and South Australia, and they chose Blandowski to be the leader (Fig. 4). He left Melbourne on the 6 December 1856 , with a large entourage, several drays and various

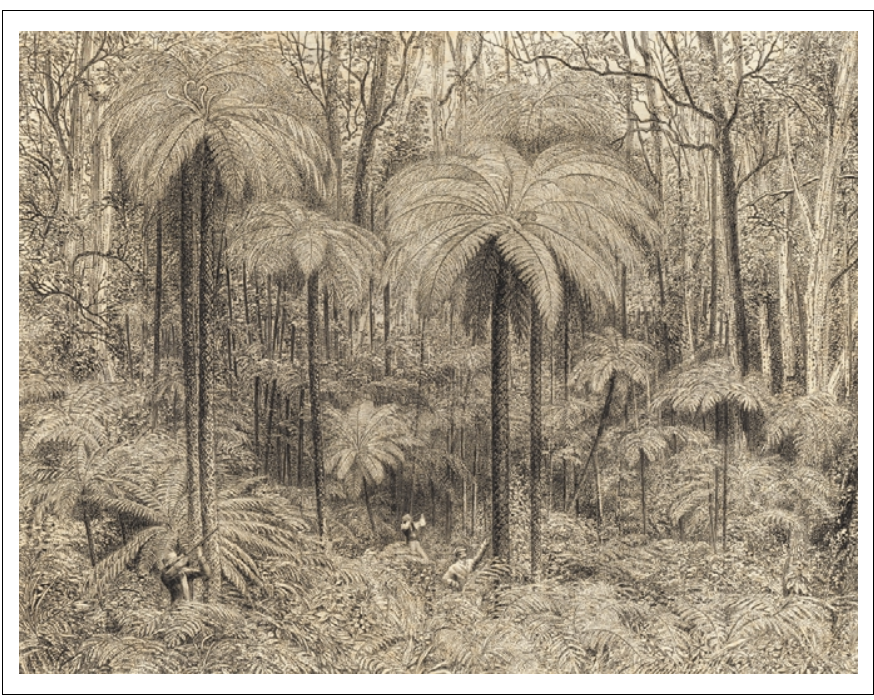

Fig. 4. Vegetation of Victoria. High Fern trees, Alsophila australis, from 40-50 ft high in the Dandenong Ranges, 20 miles east from Melbourne. Reproduced from Australia Terra Cognita by W. v. Blandowski, Melbourne. State Library of NSW, PXE 864.

recalcitrant horses and bullocks, which were the bane of the expedition. The party carried an enormous amount of gear, included bedding, clothes and food, as well as books, preservative for specimens to be collected, guns, presents for aborigines, fireworks and about $300 \mathrm{~kg}$ of photographic equipment. His second in command, and the only companion who stayed for the entire expedition, was 26 yearold Gerard Krefft (1830-1881). An expatriate German, who had arrived in Melbourne in 1852, Krefft had been recruited after Blandowski saw him copying Gould's drawings of native animals in the public library. Krefft went on to become curator at the Australian Museum in Sydney in 1860 , and he too suffered indignity when he was dismissed after the theft of gold from the museum in 1873 . He was also accused of mismanagement and the production and sale of indecent photographs at the museum [16]. But, during the 1856/1857 expedition, he was Blandowski's righthand man, the natural history illustrator and the chronicler of all Blandowski's idiosyncrasies, and especially his failings.

They crossed the Campaspe River, near the township of Echuca, and stopped at Gunbower, just to the west, for several weeks, sometimes collecting animals themselves, but more often obtaining specimens of birds, reptiles and mammals from the aborigines (Fig. 5).

Conditions were far from perfect and Blandowski left the party for a time. They met up again at Modellimin, at the junction of the Murray and Darling Rivers, near the present-day township of Mildura, where they spent most of 1857. However, Blandowski again left the encampment for three and a half weeks, traveled up the Darling River, where he claimed to have ridden 700 miles, and then in early August, went by paddlesteamer to Adelaide along the Murray River and then by boat to Melbourne. Krefft and the rest of the party persevered at Modellimin, collecting and receiving specimens from the aborigines, until they were recalled at the end of the year. In all, about 17000 specimens were collected, although many of these were individual shells and other small items, with species replicated many times. 


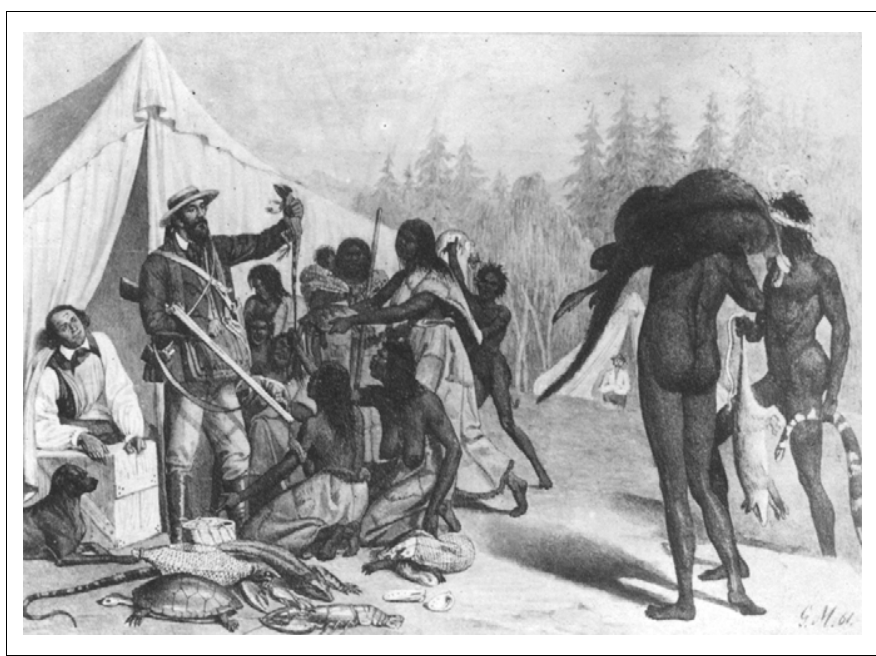

Fig. 5. Blandowski and the aborigines. Reproduced with permission from The Haddon Library, University of Cambridge, UK.

\section{Blandowski's contribution to Australian ichthyology}

There is little doubt that William Blandowski possessed enormous energy and enthusiasm in his natural history pursuits. This is clear from the speed in which he began exploring and collecting on behalf of the Museum and from the four days it took him to prepare for the lower Murray expedition. His abilities in the area of geology and mining are also apparent from his early papers [17]. His expertise in other branches of natural history are more open to question and his work has often been compared unfavourably with that of Krefft's, who went on to publish several papers on the expedition. But this is hardly a fair comparison, given the time, employment (Krefft became curator of the Australian Museum for about 13 years) and security of their respective situations. Blandowski produced a preliminary report within a few weeks of returning and left Australia barely two years later. With the ensuing inquiry and all the controversy associated with the scandal, it is not surprising that Blandowski achieved comparatively little. Krefft, on the other hand, spent the next ten years publishing the work. Interestingly, in all the subsequent letters and papers that Krefft wrote about the expedition, none makes reference to Blandowski [18]. Indeed, it is as if he never existed and that Krefft, himself, led the expedition.

Until Blandowski's arrived in Victoria, ichthyology had, like many other sciences, been largely an export industry. It was on Cook's second voyage that the first mention of a recognizable freshwater fish species was made by Tobias Furneaux, captain of the Adventure, when stopped at Van Diemen's Land in 1772. Although there were several French voyages that subsequently collected natural history specimens, it was the Baudin expedition of 1800-1804 that marked the true beginnings of Australian freshwater ichthyology [19]. For the next 50 years, most advances in this pursuit were made by European systematists, beginning with the works of George Cuvier and Achille Valenciennes in Paris (from materials from the Baudin, Duperrey and Dumont d'Urville expeditions), and then with Leonard Jenyns' descriptions of specimens supplied by Charles Darwin from his Beagle voyage, and John Richardson's analyses of samples collected on Ross' expedition in the Erebus and Terror in 1839-1843. The notable exceptions to these exports were the descriptions of Murray cod, silver perch and freshwater catfish by the surveyor Thomas Livingston Mitchell in 1838. Although not a naturalist per se, Mitchell was a keen observer, scientifically literate and aware enough of the novelty and importance of his observations to publish them widely [20].

The time was therefore ripe for a local scientist - one with intelligence, but more importantly, one who was prepared to work hard, endure privations and the harsh climate and work with the local aborigines - to push natural history forward in a way that it had not been done before. In many respects, the young colony of Australia was Blandowski's oyster and he knew it.

Although it turns out that Blandowski did not describe 19 new 'forms' as he had thought, he did discover eight new species, not an insubstantial achievement given that these represent almost a third of the entire Murray-Darling Basin freshwater fish fauna.

It is also evident from his use of scientific names and references in the text, that Blandowski was aware of the work and descriptions of Mitchell. He was certainly overly enthusiastic in his naming of the four life history stages of silver perch as different species (although he placed them all in the genus Cernua, and mentioned that they were difficult to distinguish from each other). But because the aborigines had different names for them, because they occupy different habitats during each stage, and even professional fish systematists have commonly made the same mistake with other species, this offence is certainly pardonable. Blandowski also recognized Murray cod and freshwater catfish as previously described species, and, whilst his identification of one specimen as a trout cod was probably wrong [21], although the drawing and descriptions do match some of the characteristics of this species. Furthermore, separation of Murray and trout cod proved elusive to taxonomists for many years, and the trout cod was not formerly recognized as a distinct species until 1972 [22].

From an examination of the descriptions of at least four of the species in his report, it is likely that they would have been sufficient to give Blandowski authority. If the descriptions and illustrations of the fish from the Blandowski expedition are compared with those of Mitchell, all of which are considered adequate to this day, Blandowski deserves far greater recognition than he has received. In his treatment of the bony herring (Nematalosa erebi), Blandowski provided an accurate illustration that included the number of fin rays and spines, as well as the characteristic elongated ray at the rear of the dorsal fin and the following description: 'Is of a silver colour, and has on the back, behind the dorsal fin, a very elongated back ray... Is most numerous in the Darling, but is also found above and below the junction of the Murray and Darling Rivers... It is remarkable that this fish contains an uncommon quantity of small soft bones. It grows only from 10 to 14 inches' [23].

Furthermore, Blandowski correctly identified that the fish was a new species to science, was in the herring family and, because it superficially resembled a genus that was at the time considered a herring, gave it the scientific name of Megalope caillentassart. Descriptions of similar quality were given for three other fish. The four other species were 
dealt with more summarily, despite accurate illustrations - each with the number of fin rays and spines included. But it is much less certain that these would have been sufficient to gain Blandowski authority.

It is highly likely that the extirpation of the descriptions and drawings from that key paper denied Blandowski authority for identifying at least four species of fish. What is certain is that the scandal relegated the species to scientific obscurity for between seven and 56 years. It is curious that the first of the species to be redescribed was in fact done so by Krefft himself in 1864 (flathead gudgeon, Philypnodon grandiceps) and that the bony herring was finally described by Albert Günther of the British Museum in 1868, from a specimen supplied by Krefft. Three of the eight species ended up being described by European ichthyologists. At least one species, Australian smelt (Retropinna semoni), represented a new family and waited almost 40 years to be redescribed by Weber in 1895 . The last species to be described was the Murray hardyhead, Craterocephalus fluviatilis, by Alan McCulloch in 1913. Thus, it took more than 50 years for Australian ichthyology to recover from Blandowski's tactless nomenclature and the sensitivities of the natural history establishment.

Over the years, several taxonomists have sought to recognize Blandowski for his efforts in Australian ichthyology, by naming genera of fish after him. Unfortunately, there seems to be none that has survived [24]. And so, ironically, the man whose reputation foundered on his attempts to name species of fish after others, himself remains unhonoured in this way.

\section{Postscript}

Once back in Europe in 1860, Blandowski made serious attempts to convince learned scientists to recognize the significance of his endeavours and to get his Australian work published. In both he had some success. But, it seems, Blandowski did not wallow in misery for long, and was as energetic as ever, this time in the pursuit of photography [25]. Although the photographic equipment on the expedition was not entirely successful, the photography that he did carry out in Australia is thought to be one of the first uses of photography for scientific purposes. Back in Gliwice, Blandowski rented an artist's studio and started a photographic business. He not only photographed the local gentry, presumably to earn money, but also took journalistic pictures of life in Prussia and probably produced one of the first photographic advertisements. There is no evidence that he married, and it is uncertain exactly when he died or where he was buried. What is certain, however, is that his contributions to the development of photography are, like his natural history work in Australia, largely unrecognized.

\section{Acknowledgements}

I am very grateful to the many people who assisted in the writing of this article: Jenny Nancarrow, Harry Allen, Estelle Oliver, Glenys Atkins, Adam Richardson, Aidan Baker (The Haddon Library), Zygmunt Lorenz,
Tom Darragh, Frank Job and Rory O’Brien (Museum Victoria), Martin Beckett (National Library of Australia), Dirk Spennemann and Andrzej Wiktor.

\section{References}

1 Pescott, R.T.M. (1954) Collections of a Century, National Museum of Victoria, Melbourne

2 The Argus, 4 September 1857, p. 7

3 Finney, C.M. (1993) Paradise Revealed: Natural History in 19th-Century Australia, Museum of Victoria, Melbourne, pp. 186

4 Silver perch, Bidyanus bidyanus, had already been described by the surveyor and explorer Thomas Mitchell in 1838 in his Expeditions into the Interior of Australia

5 River blackfish, Gadopsis marmoratus, had already been described by J. Richardson from collections made during the British Antarctic expedition commanded by Capt. James Ross in the HMS Erebus and Terror in 1832

6 Blandowski, W. (1857) Recent discoveries in natural history on the lower Murray. Transactions of the Philosophical Institute of Victoria 2, 124-137, pp. 131, 134

7 The Argus, 27 March 1858, p. 4

8 The Argus, 2 January 1858, p. 4

9 Melbourne Punch, 1 April 1858, p 81

10 This can be seen in the original Catalogue of the Expedition to the Junction of the Murray and Darling Rivers in the years 1856/57, led by William Blandowski, which is located in the Museum Victoria Library

11 The following account of Blandowski's life relies heavily on the comprehensive biography by Paszkowski, L. (1967) William Blandowski the first government zoologist of Victoria. The Australian Zoologist 14, 147-172

12 Home, R.W. (1998) A botanist for a continent: Ferdinand von Mueller (1825-96). Endeavour 22, 72-75

13 Thomas Darragh, pers. commun

14 Letter by the Revd August Kavel to Colonial Secretary Charles Sturt, 8 January 1850, cited in Paszkowski (1967)

15 See for example Blandowski, W. (1855) Personal observations made in an excursion towards the central parts of Victoria, including Mount Macedon, McIvor, and Black Ranges. Transactions of the Philosophical Society of Victoria 1, 50-74

16 Krefft papers. Typed account of life and dealings with the museum and Select Committee Enquiry into Management of the Australia Museum. National Library of Australia, MS 3321

17 See, for example, Blandowski, W. (1855) On the primary upheaval of the land round Melbourne, and the recent origin of gypsum or sulphate of lime in the great swamp between Batman's and Emerald Hills, Flemington, Williamnstown, and Melbourne, illustrated by a large numbers of specimens from that locality. Transactions of the Philosophical Institute of Victoria 1, 228-234

18 See for example, Krefft's letter to the Sydney Morning Herald, 21 September 1863 , p. 13

19 Humphries, P. (in press) From Van Diemen's Land to Paris: the scientific discovery of a Tasmanian fish. Forty Degrees South

20 Mitchell, T.L. (1838). Three Expeditions into the Interior of Eastern Australia, with Descriptions of Recently Explored Regions of Australia Felix and the Present Colony of New South Wales. Boone, London, p. 95

21 Iredale, T. and Whitley, G.P. (1932) Blandowski. Victorian Naturalist 44, 90-96

22 Berra, T.M. and Weatherley, A.H. (1972) A systematic study of the Australian freshwater serranid fish genus Maccullochella. Copeia 1971, 53-64

23 Blandowski, W. (1857) Recent discoveries in natural history on the lower Murray. Transactions of the Philosophical Institute of Victoria 2 , 124-137, p. 131

24 Incidentally, Krefft has 18 species and one genus named after him

25 Lewczynski, J. (1994) Wilhelm von Blandowski herby Wieniawa Zarys dzialalnosci fotograficznej. Rocznik Muzeum w Gliwicach 10, 161-185 